Article

\title{
Implementation of a Circular Economy in Ukraine: The Context of European Integration
}

\author{
Nestor Shpak ${ }^{1}$, Oleh Kuzmin ${ }^{1}$, Olga Melnyk ${ }^{2}$, Mariana Ruda ${ }^{2}$ and Włodzimierz Sroka ${ }^{3, *(D)}$ \\ 1 Management and International Business Department, Institute of Economics and Management, \\ Lviv Polytechnic National University, 79013 Lviv, Ukraine; dida_05@ukr.net (N.S.); \\ oleh.y.kuzmin@lpnu.ua (O.K.) \\ 2 Foreign Trade and Customs Department, Institute of Economics and Management, Lviv Polytechnic \\ National University, 79013 Lviv, Ukraine; olia_melnyk@ukr.net (O.M.); mariana.v.ruda@lpnu.ua (M.R.) \\ 3 Management Department, WSB University, 41-300 Dąbrowa Górnicza, Poland \\ * Correspondence: wsroka@wsb.edu.pl
}

Received: 31 May 2020; Accepted: 12 August 2020; Published: 15 August 2020

\begin{abstract}
The current model of resource management mainly contributes to mass short-term consumption, which creates an unstable and extremely critical situation on the planet. Going beyond the traditional industrial model of Take-Make-Waste, the circular economy aims to reduce waste (and therefore minimize costs) and to redefine sustainable development. This entails a gradual separation of economic activity from the consumption of scarce resources and the removal of waste from the system. In order to foreground the principles of a circular economy in Ukraine, this study analyzes its benefits based on the relevant experience of the EU. The paper also presents the results of research and content analysis on the situation of waste management in Ukraine and compares the trends using key indicators. The core of the paper is developing a conceptual model of making and coordinating management decisions on the implementation of business projects in the context of a circular economy in Ukraine. A multifactor model (the Farrar-Glauber method was further developed) has been built by identification of the main factors, i.e., the volume of generated waste from economic activity per unit of GDP at constant prices, emissions of pollutants, and capital investments for the protection of the environment. Factor coefficients indicate how many units will change the resultant trait $Y$, measured in thousand tonnes, if one of them changes by 1 (each in units of measure). It means that if the volume of waste generated from economic activity per unit of GDP at constant 2011 purchasing power parity (PPP) prices decreases by $1 \mathrm{~kg} / \$ 1000$, waste management of I-IV classes will be reduced by 952,737 thousand tonnes. The approbated model can be used to analyze the situation with recycling in the EU countries, considering the amount of capital investment in environmental protection.
\end{abstract}

Keywords: waste management; recycling; responsible consumption; circular economy; European integration

\section{Introduction}

In today's context, as society and economy strive to improve the state of the environment eroded by the long-term adverse impact of humanity, the Sustainable Development Goals (SDGs) 2030 are the benchmarks [1]. To achieve sustainable economic growth, it is critically important to reduce the negative environmental impact by changing the way we produce and consume goods and resources [2-9]. Effective management of available natural resources and new ways to dispose of toxic wastes and pollutants are also extremely important, especially in Ukraine, which is in the process of economic reforms and European integration. Moving from a linear to a circular economy, i.e., toward more sustainable consumption patterns by 2030, it is logical and urgent to encourage industries, businesses, and consumers to maximize waste treatment. 
The Responsible Consumption and Production SDG 2030 target is one of the most relevant in today's world, particularly in Europe. While in general, the European Union countries are doing well in reducing emissions and increasing the share of renewables, there are countries that are still far from reaching their goal [10]. Achieving economic growth and sustainable development is impossible without reducing the environmental impact using new production methods and ensuring responsible consumption of goods and resources [11]. One of the tools to achieve this is a circular approach to economy. It is advisable to analyze closed-loop systems where materials and resources are processed potentially endlessly, and waste and pollution are non-existent. The concept of a "circular economy" implies a fundamental rethinking of products, materials, and systems. The circular economy model is related to strategic management [12]. Although this vision is still far from reality on a macro scale, industrial symbiosis is already taking place. It involves the exchange of resources and by-products between industrial companies on a commercial basis through inter-firm processing links, meaning that waste from one business system becomes a resource for another $[13,14]$. Besides, the circular business model (CBM) concept is increasingly attractive, especially in academia [15], thus promoting the reorganization of current value creation architecture and supply chains toward a sustainable system of production and consumption [16].

The circular economy is a viable alternative to the linear economy. By maximizing the value of resources along the life cycles of the products that contain them, resources can be used more efficiently and effectively, and negative environmental, economic, and social impacts associated with the life cycle of products can be minimized [17]. Hence, the circular economy offers a clear solution that meets current policy goals. There is tremendous scope for increasing the share of the circular economy in the global economy [18].

In Ukrainian realities, the implementation of these principles is impeded by a number of reasons $[19,20]$. Despite these impediments, it is extremely important for domestic producers to realize all the potential benefits they will receive as a result of upgrading and moving from linear production to circular. Given these facts, the purpose of the study is to investigate the situation of waste management in Ukraine and to evaluate the possibilities of reorientation of Ukrainian enterprises to sustainable development principles, in particular, through the implementation of circular economy principles.

\section{Literature Review}

The circular economy concept is of great interest today because it is viewed as an operationalization for businesses to implement the much-discussed concept of sustainable development [21]. One also underlines the innovation aspect in the heart of sustained development based on circular economy component [22]. It aims to decouple prosperity from resource consumption, i.e., how we can consume goods and services and yet not depend on extraction of virgin resources and thus ensure closed loops that will prevent the eventual disposal of consumed goods in landfill sites. One can then state that by reducing our dependency on such resources, it improves our ability, and the ability of future generations to meet their needs. Therefore, the circular economy makes sustainability more likely [23]. It represents a new paradigm that will push the frontiers of environmental sustainability by transforming the relationships between ecological systems and economic activities [24]. In turn, sustainable development can be defined as development that "meets the needs of the present without compromising the ability of future generations to meet their own needs" (SDGs), and encompasses active action in three areas: economic, social, and environmental. The highest level of sustainability is also called the "circular economy approach" [25]. The current socio-economic system is based on a linear economy of take, make, waste. The main element of value creation is the material flow, which includes only the primary material at the beginning of the value chain. This has led to the fact that today humanity consumes 1.7 times more than the planet can provide [26]. More importantly, the linear economic model does not pay due attention to the environmental and social aspects, which are two of the three aspects of sustainability, and therefore the economy is not sustainable today [27]. In contrast to it, the circular economy stresses the role of the natural environment; its role is fundamental [28]. 
One cannot also forget about water scarcity, which is a very current topic in global fora dealing with sustainable development [29] and which plays a very important role in the area of economic growth [30]. There is an exacerbation of global environmental problems, including reduction of biodiversity and pollution [31]. In this regard, there is violation of the natural balance, so further development and prosperity of humanity is open to question. An indicator of atmospheric pollution is an increase in greenhouse gas emissions, which is a consequence of global warming [32-34]. One should remember that in the last couple of decades, environmental issues have become increasingly visible on the political agenda and have galvanized civil and political powers into action [35], which means, inter alia, the need for clean and environmentally friendly production of electricity, particularly production from renewable energy using hydro, wind, geothermal, solar, and biomass power plants [36]. To address this problem, green technologies are being actively promoted and developed. They are designed to reduce greenhouse gas emissions and slow the rise in temperature on the planet. However, according to experts, global warming is likely to reach 4 degrees by 2100 , when in the "pre-industrial" XIX century the temperature rise was only 0.2 degrees in 100 years. Today, the world community has set a goal to reduce warming growth by $1.5-2$ degrees by 2100 . However, the probability of achieving this is only $5 \%$ [37].

The circular economy is a renewable or regenerative production system [38]. It is also called the green economy, closed-loop economy, or non-waste economy (Majerova, 2015) [39]. This approach involves replacing the concept of an "expiration date" by repair, shifting interests toward the use of renewable energy sources, completely eliminating the use of toxic chemicals that impede the re-use of products, and eliminating waste by improving the structural characteristics of materials, product systems, and, as a result, the entire business model [40].

Going beyond the traditional industrial model Take-Make-Waste, the circular economy aims to reduce waste (and therefore minimize costs) and to redefine sustainable growth, focusing on positive benefits for society. This entails gradual separation of economic activity from the consumption of scarce resources and the removal of waste from the system. Supported by the transition to renewable energy, the circular model projects economic, natural, and social capital.

In a circular economy, the overall health of the planet is restored. Its concept recognizes the importance of the economy, but states that it needs effective work across the board for large and small businesses, for organizations and individuals, globally and locally. Recent studies for the European Commission have predicted that by 2030, Europe may receive a net benefit of 1.8 trillion euros, or 0.9 trillion euros more than in the current linear path of development (together with significant public benefits) [41].

One should add that in 2015, the European Commission adopted a new ambitious action plan to stimulate Europe's transition to a circular economy [42], which will enhance global competitiveness, sustainable economic growth, and create new jobs. In particular, this will lead to: (1) recycling of at least $65 \%$ of EU waste by 2030; (2) improving the process of determining and calculating processing rates; (3) economic incentives to market eco-friendly products and support recycling and reuse. Circularity has also opened up new business opportunities, given rise to new business models, and developed new markets, domestically and outside the EU. In 2016, circular activities such as repair, reuse, or recycling generated almost $€ 147$ billion in value added while accounting for around $€ 17.5$ billion worth of investments $[43,44]$.

Researchers also pay special attention to the sustainable economy and sustainable supply chains that could include eco-tech parks. Therefore, specific conditions must be created to establish on their technological basis the production of environmentally friendly products and to ensure maximum processing of waste [45-48].

Identifying the benefits that the circular economy would bring to societies, in particular, we should focus on the concept of decoupling the ability of an economy to grow without a corresponding increase in energy and resource use and environmental load [49]. Ukraine should use the experience of its closest neighbors, the successful EU members Czech Republic and Poland. 
One of the key elements in the circular economy is waste policy. In Ukraine, it is regulated by the Law of Ukraine "On Waste", which has been amended in recent years. However, it is worth noting that the implementation of the law is significantly delayed due to the lack of infrastructure and insufficient activity at local levels. The adoption of the National Waste Management Strategy in Ukraine by 2030 may improve the situation [50,51]. According to this Regulation, it is planned to reduce the use of primary raw materials to $80 \%$ by 2023 , and to $20 \%$ by 2030 . Furthermore, by 2023 , up to 100 waste collection centers should be established for further repair and reuse. In 2030, their number should increase to 250. According to the strategy, $8 \%$ of household waste should be sent for reuse by 2023 and 10\% from 2024 to 2030 . However, today only about $5 \%$ of waste is recycled in Ukraine. The key principle of these documents is the introduction of waste management priorities. First of all, waste generation should be prevented, then preparation for reuse; the third priority is waste recycling; then other utilization; and only the latter is removal to landfills. According to 2008/98/EU, such a procedure should be implemented at all types and at all levels in the country. This model of behavior is lacking in today's environment.

Prevention of waste generation can be implemented in two ways: (1) informing the consumer about the harm of certain products and their usual disposal (plastic, batteries); (2) motivational incentives to influence the manufacturer (prohibition to use certain materials in the manufacture of products; special requirements for packaging). When entering the market of the European Union, manufacturers should comply with EU Directives. In addition, their implementation and enforcement are required by the Association Agreement with the EU.

Data of the State Statistics Service of Ukraine [52] show that in the period 1995-2018, the volume of waste generated decreased by $14.05 \%$, with a sharp decline in 2014. However, in 2017-2018, the level increased again. In addition, the volume of waste disposal has been significantly reduced and only $10 \%$ of waste is recycled and reused [53]. The Lviv region is one of the most economically active and developed in Ukraine, so it is advisable to evaluate the nature of waste management in this particular area. The study was conducted using data from the Main Directorate of Statistics in the Lviv region.

\section{Materials and Methods}

Analyzing the relevant literature sources on the subject, we found that they are usually qualitative research on the development of the concept of the circular economy in the world, but there is no detailed explanation and quantification of the factors that play a crucial role in waste management based on sustainable development and a circular economy, especially in developing countries. In this case, it makes sense to search and develop tools for management decisions in the field of waste management based on the results of statistical analysis and construction of an appropriate mathematical model to describe the identified dependencies, based on the European experience.

As for the research methodology applied for this paper, it consists of a three-step procedure, including:

1. Step 1-formulation of the research hypothesis;

2. Step 2-selection and review of profile sources on the subject of research, which may have a practical interest for the implementation of circular economy principles in Ukraine;

3. Step 3-selection of statistical indicators for the quantitative analysis of the factors influencing the general volume of waste management, and development on this basis of the conceptual model of decision-making.

The hypothesis of this study is as follows. Assume that the preconditions for the transition to a circular economy in Ukraine depend on certain factors (information support, effectiveness of legislation, environmental awareness, sufficient financial resources, requirements from the European community to reorganize production to implement joint investment projects, etc.). That is, we set ourselves the task to explain trends in waste management in Ukraine by determining the quantitative patterns between "waste management of I-IV classes" (Y-resultant trait) and "volume of waste 
generated from economic activity per unit of GDP", "emissions of pollutants", and "capital investment in environmental protection". Additionally, to also substantiate the received results for development of the conceptual model of decision-making in the system of interactions between the state, business, and the consulting agency.

Thus, our hypothesis actualizes the objective possibilities of implementing the principles of a circular economy in Ukraine, sets the algorithm for implementing the purpose of the study, explains the aspect of decision-making at the macro level in terms of effective interaction of "business-state", in particular, in the field of social responsibility.

Using content analysis, our study: (1) analyzes global trends in sustainable development; (2) highlights the benefits of the circular economy, in particular, for developing EU countries; and (3) analyzes statistics describing the status of waste management in Ukraine. This detailed analysis allowed us to build a multifactorial model with the separation of factors affecting waste management and to test it on the example of Ukraine's economy. Finally, upon identifying the most important factors in the survey of top managers, we proposed specific steps for greening business systems on the basis of sustainable development and a circular economy.

To find evidence for a formalized hypothesis, we used a statistical method that calculates quantitative expectations. At the same time, the empirical method, observations, and some thought-logical methods, including induction and deduction, were used.

\section{Results and Discussion}

One should underline that transition to a circular model of the economy in the coming decades will be not just a way to boost a company's environmental friendliness, but a necessary measure that will further ensure profitability and create value. In Ukraine, in particular, this is due to three basic reasons. The first reason is limited resources. If the planet's resources are used at the same level as they are today, by the end of the coming decade, a significant deficit will form, causing a serious crisis. In addition, due to the high demand for resources, their value is increasing, which, in its turn, increases the level of enterprise costs and, consequently, the price of goods. Thus, using a circular type of production, enterprises reduce the pressure on demand for primary raw materials and protect themselves from fluctuations and impacts in the commodity market, as they provide themselves with the necessary resources. The second reason relates to legislative changes and new approaches to governance. Legislative reform is being actively pursued at both local and global levels, stimulating the transition of enterprises to the latest production approaches, including circular ones. Moreover, innovative management approaches are being developed-they treat production waste not as a problem, but as an opportunity. In addition, the third reason relates to the prospects for production optimization. As the circular approach to production requires the use of innovative methods and tools, it is necessary to change and modernize production processes. This will optimize production by automating and reducing downtime.

Studies on the effectiveness of methods employed in the EU countries show a positive impact on emission reductions, job creation, and trade balance [54-62]. Thus, companies operating on a circular model in Europe have a number of advantages at the micro and macro levels. Let us focus on the top benefit. First of all, companies reduce their dependence on commodity markets and, as a consequence, become less sensitive to price fluctuations. This is due to the fact that enterprises independently provide themselves with the necessary raw materials, which by their nature are waste or goods whose useful life has expired. Second, businesses have the opportunity to influence the cost of production by reducing the cost of raw materials. As noted, the trend of changes in the price of raw materials in recent years is in a clearly upward direction, which entails higher costs for enterprises. In contrast, self-sufficient business entities are able to reduce the cost of goods through the use of recycled resources $[63,64]$. As a result, both sales volume and productivity can increase. Third, the shift to a circular production model will enable businesses to further reduce their tax burden, as tax rates are projected to increase for businesses that do not use resource- and energy-efficient methods. The outcome of operations 
is important to companies, so reducing tax deductions will allow them to more effectively use the working capital of the enterprise to increase the efficiency of operations.

The construction of a multifactor econometric model requires a study to meet certain prerequisites. First of all, the selected exogenous factors must be independent, i.e., there must be no multicollinearity. For this purpose, it is necessary to use the known Farrar-Glauber test (method), which is based on the assessment of the calculated value of $\chi^{2}$-criterion.

To analyze the factors influencing the volume of waste management in grades I-IV (thousand tonnes) across Ukraine, three independent factors were selected. Presence of common multicollinearity was verified by $\chi^{2}$-criterion:

$$
x_{\mathrm{p}}^{2}=-\left(\mathrm{n}-1-\frac{(2 \mathrm{~m}+5)}{6}\right) \ln (\operatorname{det} \mathrm{R})
$$

where $\mathrm{n}$ is the sample size $(\mathrm{n}=13), \mathrm{m}$ is the number of factors $(\mathrm{m}=3)$. $\mathrm{R}$ is a correlation matrix whose elements are pairwise correlation coefficients. In Table 1, the input data (three exogenous factors were selected) for the construction of the statistical model are presented. It provides the impact on the volume of waste management of I-IV classes; thousands of tons in Ukraine.

We construct a correlation matrix $(\mathrm{R})$ of the form:

\begin{tabular}{|c|c|c|c|}
\hline 1.00 & -0.13 & 0.29 & \\
\hline-0.13 & 1.00 & -0.85 & $=0.25$ \\
\hline 0.29 & -0.85 & 1.00 & \\
\hline
\end{tabular}

where $\mathrm{R}=0.25$ is the determinant of the correlation matrix. In our case $\chi^{2}=14.2$. The tabular value of $\chi^{2}=14.4$ for a given probability $p=0.95$ and the degree of freedom $\mathrm{k}=\frac{1}{2} \mathrm{~m}(\mathrm{~m}-1)=3$, then there is an inequality $\chi^{2} \leq \chi^{2}$ cr, which indicates that the total multicollinearity is absent.

With the LINEST (Excel app) function, an econometric model is built. The results of LINEST are as follows:

\begin{tabular}{cccc}
\hline $\mathbf{A}_{\mathbf{3}}$ & $\mathbf{A}_{\mathbf{2}}$ & $\mathbf{A}_{\mathbf{1}}$ & $\mathbf{A}_{\mathbf{0}}$ \\
\hline $\mathrm{A}_{3}=0.007$ & $\mathrm{~A}_{2}=6.884$ & $\mathrm{~A}_{1}=952.737$ & $\mathrm{~A}_{0}=-779,805.610$ \\
\hline 0.011 & 29.752 & 123.114 & $242,713.627$ \\
\hline $\mathrm{R}^{2}=0.892$ & $70,040.045$ & & \\
\hline $\mathrm{F}_{\mathrm{p}}=24.656$ & $\mathrm{~K}_{2}=9$ & & \\
\hline $362,856,318,533.151$ & $44,150,471,636,721$ & & \\
\hline
\end{tabular}

The econometric model is the following:

$$
Y=-779,805.61+952.737 \times X_{1}+6.884 \times X_{2}+0.007 \times X_{3}
$$

The coefficient of determination $\mathrm{R}^{2}=0.886$. Fisher's criterion confirms the adequacy of the statistical model to the aggregate data $\left(\mathrm{F}_{\text {calc }} \geq \mathrm{F}_{\text {table }}\right) . \mathrm{F}_{\text {calc }}=3.68 . \mathrm{F}_{\text {table }}=5.56$ (at probability $p=0.95$, degrees of freedom $\mathrm{k} 1=3, \mathrm{k} 2=9$ ). 
Table 1. Input data for the construction of a multifactor model studying the impact on waste management in Ukraine during 2006-2018.

\begin{tabular}{|c|c|c|c|c|c|}
\hline No. & Year & $\begin{array}{l}\text { Volume of Waste Generated from } \\
\text { Economic Activity Per Unit of } \\
\text { GDP at Constant } 2011 \text { Purchasing } \\
\text { Power Parities (PPP), kg/ } \$ 1000\end{array}$ & $\begin{array}{l}\text { Emissions of Pollutants, } \\
\text { Thousand Metric Tonnes }\end{array}$ & $\begin{array}{c}\text { Capital Investment in Environmental } \\
\text { Protection, Thousand Ukrainian } \\
\text { Hryvnia (UAH) }\end{array}$ & $\begin{array}{l}\text { Waste Management of } \\
\text { I-IV Classes, Thousand } \\
\text { Metric Tonnes } \\
\text { (Y-Resultant Trait) }\end{array}$ \\
\hline 1 & 2006 & 788.3 & 7027.6 & $2,194,188.5$ & 1967 \\
\hline 2 & 2007 & 897.5 & 7380.0 & $3,080,687.6$ & 2061.4 \\
\hline 3 & 2008 & 688.2 & 7210.3 & $3,731,400.4$ & 2017.4 \\
\hline 4 & 2009 & 715.4 & 6442.9 & $3,040,732.7$ & 1174.9 \\
\hline 5 & 2010 & 1177.3 & 6678.0 & $2,761,472.1$ & $483,721.5$ \\
\hline 6 & 2011 & 1172.5 & 6877.3 & $6,451,034.6$ & $431,848.7$ \\
\hline 7 & 2012 & 1177.4 & 6821.1 & $6,589,336.5$ & $434,296.8$ \\
\hline 8 & 2013 & 1173.9 & 6719.8 & $6,038,783.0$ & $436,217.7$ \\
\hline 9 & 2014 & 1001.4 & 5346.2 & $7,959,853.9$ & $313,922.8$ \\
\hline 10 & 2015 & 977.4 & 4521.3 & $7,675,597.0$ & $245,893.4$ \\
\hline 11 & 2016 & 904.2 & 4498.1 & $13,390,477.3$ & $243,115.7$ \\
\hline 12 & 2017 & 1089.8 & 3974.1 & $11,025,535.2$ & $270,922.2$ \\
\hline 13 & 2018 & 1015.7 & 3866.7 & $10,074,279.3$ & $274,210.5$ \\
\hline
\end{tabular}

Source: own elaboration based on the basis of the State Statistics Service of Ukraine [52]. 
Factor coefficients indicate how many units will change the resultant trait $Y$, measured in thousand tonnes, if one of them changes by 1 (each in units of measure). For example, if the volume of waste generated from economic activity per unit of GDP at constant 2011 PPP prices decreases by $1 \mathrm{~kg} / \$ 1000$, waste management of I-IV classes will be reduced by 952,737 thousand tonnes. Based on the analysis of the coefficients for the influencing factors, one can draw the following conclusions:

1. All factor features have a positive effect on the resulting indicator-waste management I-IV classes, thousand tons;

2. Increase in the volume of waste generated from economic activity per unit of GDP at constant 2011 purchasing power parities by $1 \mathrm{~kg} / \$ 1000$ leads to an increase in the resulting indicator-waste management I-IV classes by 952,737 thousand tonnes;

3. Increase in emissions of pollutants per 1 thousand tons leads to an increase in the volume of waste management I-IV classes by 6884 thousand tons;

4. Growth of capital investment in environmental protection by thousand UAH leads to an increase in the volume of waste management of I-IV classes by 0.007 thousand tonnes.

The circular economy can be viewed at several levels: micro, macro, meso, and mega levels. The area of responsibility of enterprises is the micro level, where action in terms of production, consumption, and waste management is possible. In the latter area, the main tool is the system of product recycling, i.e., formation of a circular type of production. At the same time, it should be assessed how the implementation of the circular economy techniques at the macro level relates to the efficiency and effectiveness of businesses in various industries. We conducted a survey interviewing top managers of Ukrainian industrial enterprises from across the country and asking them to answer a number of questions. One of them was "Please assess the importance of implementing the principles of circular economy (in \% from 0 to 100) in your industry in the context of Ukraine's European integration", as shown in Table 2.

Table 2. Importance of implementing the principles of a circular economy in the particular sectors (0 to $100 \%)$.

\begin{tabular}{|c|c|c|c|c|c|}
\hline \multirow{2}{*}{ Sector } & \multicolumn{3}{|c|}{ Importance Rating Scale, (Point Estimate) } & \multirow{2}{*}{$\begin{array}{c}\text { Weighted } \\
\text { Average }\end{array}$} & \multirow{2}{*}{ Rating } \\
\hline & $\begin{array}{c}\text { Low } \\
\text { (Up to } 30 \%)\end{array}$ & $\begin{array}{l}\text { Moderate } \\
(31-70 \%)\end{array}$ & $\begin{array}{c}\text { High } \\
(\mathbf{7 1 - 1 0 0 \% )}\end{array}$ & & \\
\hline $\begin{array}{l}\text { Agriculture, forestry, } \\
\text { and fisheries }\end{array}$ & 25 & 45 & 30 & 51.75 & 6 \\
\hline Chemical industry & 13 & 19 & 68 & 69.25 & 2 \\
\hline Electricity supply & 24 & 26 & 50 & 59.1 & 3 \\
\hline Food industry & 34 & 18 & 48 & 54.9 & 5 \\
\hline $\begin{array}{l}\text { Other economic } \\
\text { activities }\end{array}$ & 20 & 56 & 24 & 51.4 & 7 \\
\hline Mining industry & 14 & 10 & 76 & 71.7 & 1 \\
\hline Construction & 22 & 37 & 41 & 56.65 & 4 \\
\hline
\end{tabular}

The method of ranking was used for evaluation. First of all, the weighted average values were determined. They are average in each defined interval from 1 to 100\%, i.e., in the first interval "low score up to $30 \% "$, this value is equal to $15 \%$ in the middle of the interval. Similarly, in the second interval, the average value is $50 \%$, and in the third interval- $85 \%$. The percentages of the respondents' answers will act as the weight (importance) of the mean. In Table 2, the results of the respondents' ranking on the questionnaire are presented. Note that the highest rating value corresponds to a rating of 1 .

Thus, the survey showed that, according to the surveyed managers of enterprises among all sectors of the economy of Ukraine in the mining industry, it is most important to move to the principles 
of a circular economy. In addition, the questionnaire made it clear what factors are critical for the successful adjustment of the enterprise to the principles of a circular economy, as shown in Figure 1.

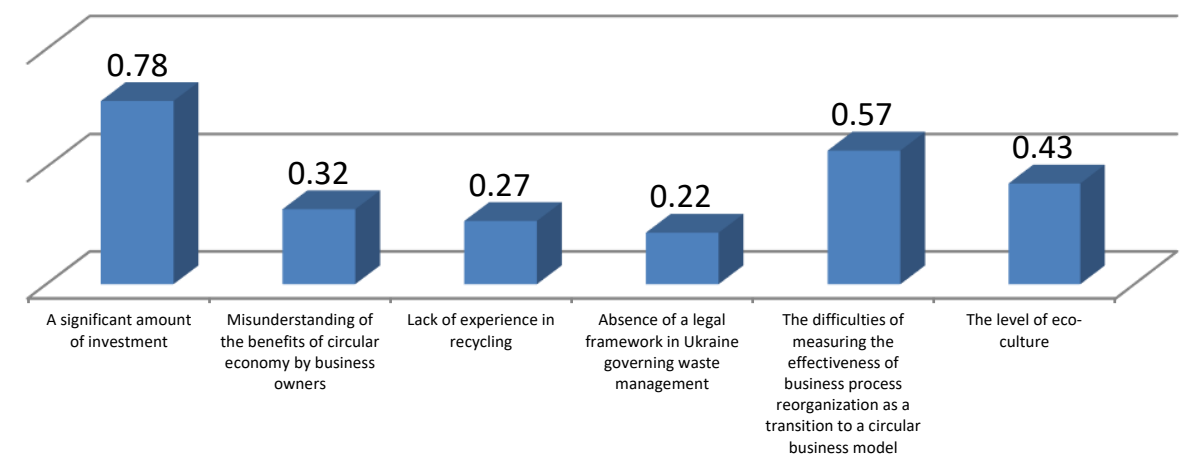

Figure 1. Distribution of answers of the respondents about the factors that are critical for the successful adjustment of their enterprise to the principles of a circular economy (up to three answers could be selected). Source: own elaboration.

As one can see from Figure 1, when it comes to implementing the principles of the circular economy, the main problems for Ukrainian business are the large amount of investments required, the complexity of measuring the efficiency of business process reorganization, and the low level of eco-culture.

Taking into account the results obtained, it is advisable to develop the conceptual model of making and coordinating management decisions on the implementation of business projects in the context of a circular economy, as shown in Figure 2.

It is proposed to develop the criteria for the decision-making process at the macro level in terms of effective interactions of "business-state", in particular, in the field of social responsibility. The main criteria are as follows: reduce, reuse, recycle, responsibility, global social corporate responsibility. It is also important to ensure: (a) economic growth without increasing consumption and landfills; (b) maximum efficiency at each stage of the product/service life cycle; (c) all participants involved in the economic chain must create a new product (a team of companies that move and think in one direction should be formed); (d) principles of product durability (longer service life); (e) environmental friendliness and environmental protection; (f) rethinking the use of the product, exchange, or joint use; (g) reducing the use of natural resources; (h) repair and maintenance of a product that has defects; reorientation of production; and (i) incineration to recover energy expended on production.

The business model based on waste assumes the creation and reorganization of existing companies for processing and use of waste as raw material. It is necessary to indicate directions the state should stimulate through funds, public procurement, capital investments in environmental protection, assistance in obtaining grant funds for joint implementation with the EU of investment business projects in the field of the circular economy, "green" lending, preferential lending to small and medium sized enterprises (SMEs), and consulting activities (creating the agency for the development of the circular economy in Ukraine in accordance with national legislation and adopted EU directives). It should also be noted that the first step to support eco-trends is the implementation of a comprehensive waste management program, which provides a wide range of activities to be implemented by the companies. Such a program provides for waste sorting, recycling, and reuse in production, sharing, and disposal of waste that is not suitable for further processing. 


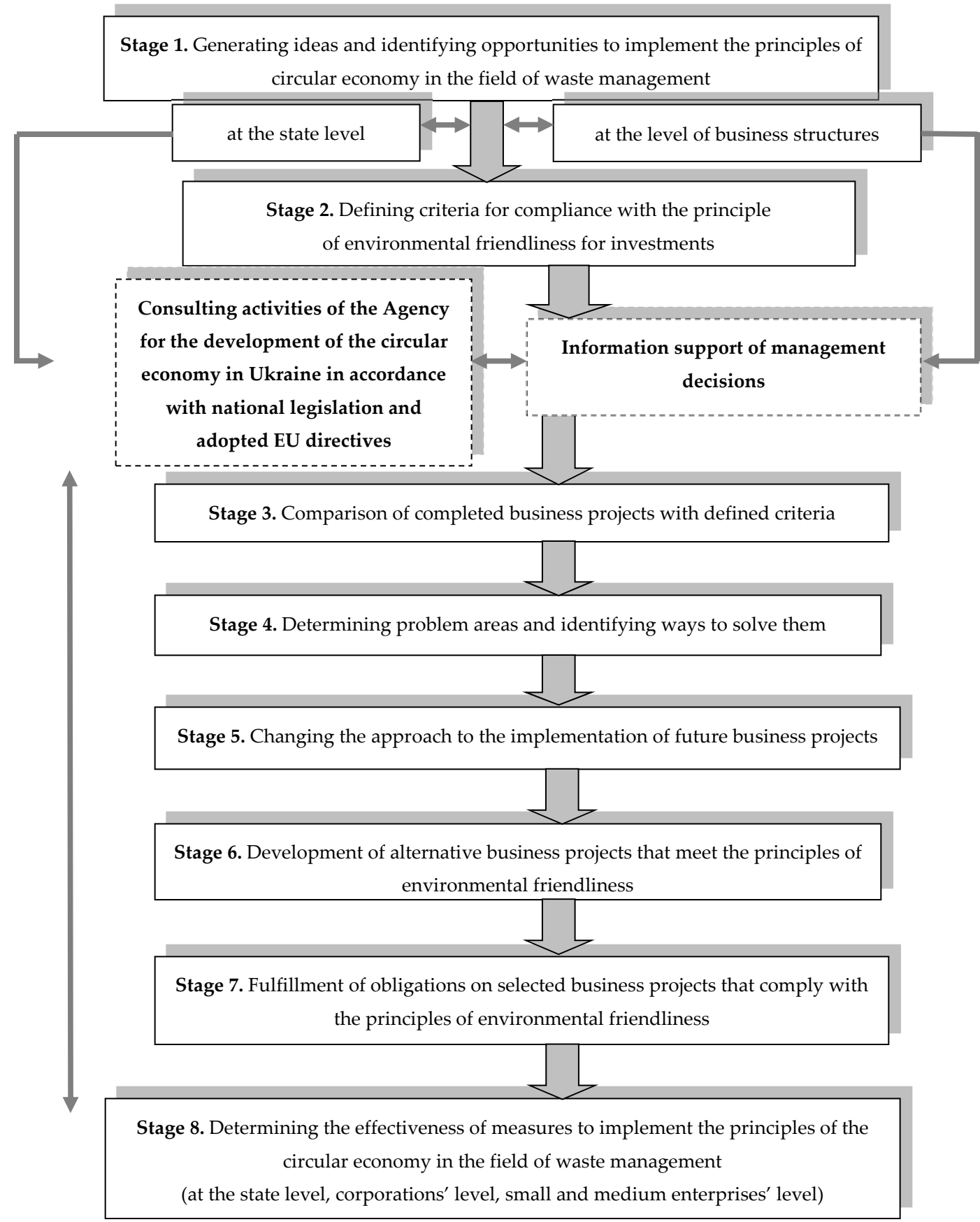

Figure 2. Conceptual model of making and coordinating management decisions on the implementation of business projects in the context of circular economy development in Ukraine. Source: own elaboration.

Though it is a conceptual paper, its findings are in line with the findings of other scholars dealing with the topic, like Lieder and Rashi [65], Kirchherr et al., 2017 [66], and Sanchez et al. [67]. In addition, one should also add that to some extent the results obtained are in line with the findings of Geng et al., 2009, 2012 [68,69], who in relation to the circular economy analyzed macro-level indicators related to: (1) external resources used; (2) recycling, and water consumed; and (3) pollutant emissions, as well as Su et al., 2013 [41] (e.g., raw material use and recycling, pollution control, and waste administration and management).

It should be strongly underlined that the waste management in the EU faces a number of challenges in relation to the circular economy (CE) model. However, there are some targets (economic, environmental, and social) and recommended actions for the sustainable and circular economy policy 
that should be done in Ukraine too. The main tasks are increasing waste and resource efficiency, reducing global pressure on resources and rising insecurity of supply, and building a recycling society. According to the Green Deal, we should prioritize such goals as (1) building a more competitive Europe in co-creation with economic actors, consumers, citizens, and civil society organizations; (2) building a cleaner and climate-neutral Europe in co-creation with economic actors, consumers, citizens, and civil society organizations; and (3) building a fair and prosperous society [70]. Therefore, recommended measures for present and future EU members should be aimed at: delivering improvements or innovative business models on the market; eco-design - ease of dismantling products to reduce raw material use in new products; promoting a collaborative economy, such as sharing cars, bikes, clothes, and working spaces; provide incentives and use economic instruments, such as taxation, to ensure that product prices better reflect environmental cost; developing the necessary services for consumers in this regard (maintenance/repair services); boosting markets for secondary raw materials; delivering environmental impact measurement in product and process design and in providing consumers with better information on environmentally sustainable choices; delivering safe usage of waste as a source of secondary materials; boosting innovation by financial support under the EU; creating a network of platforms aimed at collaboration on the regional, national, and international levels in the area of waste management; supporting recycling technologies' development by innovative financial instruments, reflecting resource issues in accounting rules for companies, clarifying the sustainability responsibilities of financial institutions (fiduciary duties); foster circular industrial collaboration among SMEs; incentivizing and supporting waste reduction and high-quality separation by consumers; improving modelling tools to capture the benefits of the $\mathrm{CE}$ on greenhouse gas emission reduction at EU and national levels; promoting direct investment in waste management options at the top of the waste hierarchy (prevention, re-use, recycling); education of different groups of stakeholders (children, students, individuals, policymakers) on the importance of the sustainable future.

\section{Conclusions}

The circular economy is gaining growing attention as a potential way to increase prosperity, while reducing demands on finite raw materials and minimizing negative externalities. Such a transition, however, requires a systemic approach, which entails moving beyond incremental improvements to the existing model as well as developing new collaboration mechanisms. The implementation of circular approach tools is extremely resource intensive and requires a thoroughly developed mechanism. This modern-day approach makes it possible to reduce the environmental burden, increase energy efficiency, and create a number of additional benefits for society.

One should, however, state that the circular economy is not simply a method of dealing with a large amount of waste. All measures foreseen in this context are aimed primarily at sustainable development and economic growth. It should be noted that the goal of sustainable development is in many ways in line with the others; in particular, those related to economic growth and development of industry, innovation, and infrastructure. The analyzed situation with waste in Ukraine only confirms the trends typical for the EU countries, especially Central and Eastern European ones. For sure, the EU's experience is critically important to Ukraine's development, but this process is still accompanied by the lack of a unified system and tools that would be able to establish effective ways of managing waste. Another problem is the insufficient environmental awareness of the Ukrainian society. Despite this situation, there is a tendency toward a gradual increase in the share of treated waste used for energy production. However, these are only the first steps toward a full transition to a circular economy that will allow not only businesses but also the entire country to become more environmentally responsible, which, in turn will lead to further economic growth. It should be noted that given the Ukrainian economic realities, the transition to a circular economy will be long and difficult. That is due to the lack of a mechanism for its implementation or financial support for the necessary measures. Thus, enterprises without sufficient financial resources to carry out reorganization and modernization of production are waiting and looking for potential sources of financing. Moreover, the culture of waste 
management among the population is not fully developed, which significantly impedes the access of enterprises to the base of potential raw materials. Therefore, a clear mechanism for collecting, sorting, and distributing waste should be developed first and foremost. As a result, the raw material base will be formed, and the enterprises will be able to use it for further processing and introduction into their production processes.

The core of the paper was developing a conceptual model of making and coordinating management decisions on the implementation of business projects in the context of a circular economy in Ukraine. As a result, a multifactor model has been built by identification of the main factors, including the volume of generated waste from economic activity per unit of GDP at constant prices, emissions of pollutants, and capital investments for the protection of the environment.

This study contributes to the theory in several ways. First of all, it constitutes the next work on a circular economy based on the example of a developing country. The findings of this study can also be relevant to practice as it gives some recommendations to the governments and policymakers on how to increase the effectiveness of waste management. There is no doubt that this will be very beneficial to the economic development of the country. In addition, the findings of the study may be useful to formulate research hypotheses that could be tested on larger samples. Of course, our study is not free from some limitations. First of all, it relates to the analysis of the situation existing in one developing country only. This means that further research is essential. Despite this fact, we believe that our study presents the real picture of the circular economy in the emerging economy. Additionally, at the same time the approbated model, based on Ukraine's economy in the field of waste management, can be used to analyze the situation with recycling in the EU countries, considering the amount of capital investment in environmental protection.

Author Contributions: All authors contributed to the development of the current paper. The concept and methodology were prepared by N.S. and O.K., while the detailed literature review, discussion, and recommendations have been done by O.M. and M.R. The revision (review and editing) of the proposed literature review, discussion, and recommendations have been done by N.S., W.S., and O.M. All authors have read and agreed to the published version of the manuscript.

Funding: The article was prepared in the framework of the J. Monnet Module "EU competitiveness boosting: circular economy" (610641-EPP-1-2019-1-UA-EPPJMO-MODULE), which is being realized by the Department of Foreign Trade and Customs of Lviv Polytechnic National University with the support of the Erasmus+ Programme of the European Union. The European Commission support for the production of this article does not constitute an endorsement of the contents which reflects the views only of the authors, and the Commission cannot be held responsible for any use which may be made of the information contained therein. The project was funded within the auspices of the programme of the Minister of Science and Higher Education entitled "Regional Initiative of Excellence" in 2019-2022, project number 018/RID/2018/19; amount of funding: PLN 10,788,423.16.

Conflicts of Interest: The authors declare no conflict of interest.

\section{References}

1. Sustainable Development Goals. Available online: https://sustainabledevelopment.un.org/?menu=1300 (accessed on 16 April 2020).

2. Anttonen, M.; Lammi, M.; Mykkänen, J.; Repo, P. Circular Economy in the Triple Helix of Innovation Systems. Sustainability 2018, 10, 2646. [CrossRef]

3. Avdiushchenko, A.; Zając, P. Circular economy indicators as a supporting tool for European regional development policies. Sustainability 2019, 11, 3025. [CrossRef]

4. Bigano, A.; Śniegocki, A.; Zotti, J. Policies for a more dematerialized EU economy. Theoretical underpinnings, political context and expected feasibility. Sustainability 2016, 8, 717. [CrossRef]

5. Clift, R.; Allwood, J. Rethinking the economy. Chem. Eng. 2011, 837, 30-31.

6. Geissdoerfer, M.; Savaget, P.; Bocken, N.M.P.; Hultink, E.J. The circular economy-A new sustainability paradigm? J. Clean. Prod. 2017, 143, 757-768. [CrossRef]

7. Guske, A.-L.; Jacob, K.; Hirschnitz-Garbers, M.; Peuckert, J.; Schridde, S.; Stinner, S.; Wolff, F.; Zahrnt, D.; Ziesemer, F. Stories that Change Our World? Narratives of the Sustainable Economy. Sustainability 2019, 11, 6163. [CrossRef] 
8. Luttenberger, L.R. Waste management challenges in transition to circular economy-Case of Croatia. J. Clean. Prod. 2020, 256, 120495. [CrossRef]

9. Mesterházy, Á.; Oláh, J.; Popp, J. Losses in the grain supply chain: Causes and solutions. Sustainability 2020, 12, 2342. [CrossRef]

10. Chovancová, J.; Tej, J. Decoupling economic growth from greenhouse gas emissions: The case of the energy sector in V4 countries. Equilib. Q. J. Econ. Econ. Policy 2020, 15, 235-251. [CrossRef]

11. Ellen MacArthur Foundation. Towards a Circular Economy: Business Rationale for an Accelerated Transition. Available online: https://www.ellenmacarthurfoundation.org/publications/towards-a-circular-economybusiness-rationale-for-an-accelerated-transition (accessed on 15 December 2019).

12. Vargas-Hernández, J.; Medrano, M. The Circular Economy. Rev. Gest. Sustentabilidade 2019, 1, $298-309$. [CrossRef]

13. Zielińska, A. Comparative Analysis of Circular Economy Implementation in Poland and other European Union Countries. J. Int. Stud. 2019, 12, 337-347. [CrossRef]

14. Ünal, E.; Shao, J. A taxonomy of circular economy implementation strategies for manufacturing firms: Analysis of 391 cradle-to-cradle products. J. Clean. Prod. 2019, 212, 754-765. [CrossRef]

15. Chen, L.C.; Hung, P.; Ma, H.W. Integrating circular business models and development tools in the circular economy transition process: A firm-level framework. Bus. Strat. Environ. 2020. [CrossRef]

16. Hofmann, F. Circular business models: Business approach as driver or obstructer of sustainability transitions? J. Clean. Prod. 2019, 224, 361-374. [CrossRef]

17. Androniceanu, A.; Gherghina, R.; Ciobanasu, M. The interdependence between fiscal public policies and tax evasion. Adm. Manag. Public 2019, 32, 32-41. [CrossRef]

18. Brandão, M.; Lazarevic, D.; Finnveden, G. Prospects for the Circular Economy and Conclusions. Circular Economy Update. Overview of Circular Economy in Europe 2019. Final Report. Ecopreneur.eu. Available online: https://circulareconomy.europa.eu/platform/sites/default/files/ecopreneur-circular-economyupdate-report-2019.pdf (accessed on 19 April 2020).

19. Shpak, N.; Kyrylych, T.; Greblikaite, J. Diversification Models of Sales Activity for Steady Development of an Enterprise. Sustainability 2016, 8, 393. [CrossRef]

20. Shpak, N.; Odrekhivskyi, M.; Doroshkevych, K.; Sroka, W. Simulation of innovative systems under industry 4.0 conditions. Soc. Sci. 2019, 8, 202. [CrossRef]

21. Murray, A.; Skene, K.; Haynes, K. The Circular Economy: An Interdisciplinary Exploration of the Concept and Application in a Global Context. J. Bus. Ethics 2017, 140, 369-380. [CrossRef]

22. Hysa, E.; Kruja, A.; Rehman, N.U.; Laurenti, R. Circular Economy Innovation and Environmental Sustainability Impact on Economic Growth: An Integrated Model for Sustainable Development. Sustainability 2020, 12, 4831. [CrossRef]

23. Sauvéab, S.; Bernard, S.; Sloan, P. Environmental sciences, sustainable development and circular economy: Alternative concepts for trans-disciplinary research. Environ. Dev. 2016, 17, 48-56. [CrossRef]

24. Genovese, A.; Pansera, M. Circular Economy at a crossroad: Technocratic Eco-Modernism or Convivial Technology for Social Revolution? Capital. Nat. Soc. 2020. [CrossRef]

25. Šebestová, J.; Sroka, W. Sustainable development goals and SME decisions: The Czech Republic vs. Poland. J. East. Eur. Cent. Asian Res. 2020, 7, 39-50. [CrossRef]

26. Framework for Implementing the Principles of the Circular Economy in Organizations_Guide; The British Standards Institution: London, UK, 2017. Available online: https://www.thenbs.com/PublicationIndex/documents/ details?Pub=BSI\&DocID=317511 (accessed on 15 August 2020).

27. Pialot, O.; Millet, D.; Bisiaux, J. “Upgradable PSS": Clarifying a new concept of sustainable consumption/production based on upgradability. J. Clean. Prod. 2017, 141, 538-550. [CrossRef]

28. Pomponi, F.; Moncaster, A. Circular economy for the built environment: A research framework. J. Clean. Prod. 2017, 143, 710-718. [CrossRef]

29. Fang, C.; Bao, C.; Huang, J. Management implications to water resources constraint force on socio-economic systemin rapid urbanization: A case study of the Hexi Corridor, NW China. Water Resour. Manag. 2007, 21, 1613-1633. [CrossRef]

30. Hejduková, P.; Kureková, L. Water scarcity: Regional analyses in the Czech Republic from 2014 to 2018. Oecon. Copernic. 2020, 11, 161-181. [CrossRef] 
31. Kliestikova, J.; Krizanova, A.; Corejova, T.; Kral, P.; Spuchlakova, E. Subsidies to Increase Remote Pollution? Sci. Eng. Ethics 2018, 24, 755-767. [CrossRef]

32. UNEP: Global Environmental Outlook 5. Chapter 2 Atmosphere/UNEP. 2012. Available online: http://web.unep. org/geo/sites/unep.org.geo/files/documents/geo5_report_c5.pdf (accessed on 19 October 2019).

33. Strielkowski, W.; Lisin, E.; Gryshova, I. Climate policy of the European Union: What to expect from the Paris Agreement? Rom. J. Eur. Aff. 2016, 16, 68-77.

34. Oláh, J.; Krisán, E.; Kiss, A.; Lakner, Z.; Popp, J. PRISMA Statement for Reporting Literature Searches in Systematic Reviews of the Bioethanol Sector. Energies 2020, 13, 2323. [CrossRef]

35. Dan, H. Culturally green-An investigation into the cultural determinants of environmental performance. Forum Sci. Oecon. 2019, 7, 107-126. [CrossRef]

36. Pawliczek, A.; Zimmermannova, J. Evaluation of the economic indicators of a company-prosumer using photovoltaics. Forum Sci. Oecon. 2018, 6, 51-64. [CrossRef]

37. UNEP: The Emissions Gap Report 2017. 2017. Available online: https://wedocs.unep.org/bitstream/handle/ 20.500.11822/22070/EGR_2017.pdf (accessed on 26 October 2019).

38. Androniceanu, A.; Popescu, C.R. An inclusive model for an effective development of the renewable energies public sector. Adm. Manag. Public 2017, 28, 81-96.

39. Majerova, J. Analysis of Slovak consumer's perception of the green marketing activities. Procedia Econ. Financ. 2015, 26, 553-560. [CrossRef]

40. A Long-Term Strategy for a European Circular Economy-Setting the Course for Success. Think 2030. 2018. Available online: https://ieep.eu/uploads/articles/attachments/f99f1ac9-83a0-47e0-a0a2-74f3ce528ad8/ Think\%202030\%20Circular\%20Economy.pdf?v=63710011292 (accessed on 27 October 2019).

41. EU and China Step up Their Cooperation on Environment, Water and Circular Economy. Available online: https://ec.europa.eu/info/news/eu-and-china-step-their-cooperation-environment-waterand-circular-economy-2019-apr-01_en (accessed on 21 October 2019).

42. Circular Economy. Implementation of the Circular Economy Action Plan. European Commission. 2019. Available online: http://ec.europa.eu/environment/circular-economy/index_en.htm (accessed on 20 May 2020).

43. Circular Economy Would Increase European Competitiveness and Deliver Better Societal Outcomes, New Study Reveals. Available online: https://www.ellenmacarthurfoundation.org/news/circular-economywould-increase-european-competitiveness-and-deliver-better-societal-outcomes-new-study-reveals?fbclid= IwAR1xIepVJ1j1Z1PJHfK1LPDOXzqJBYOox7EQfAoQFTmfBTAD72t9Mw69jkQ (accessed on 20 May 2020).

44. Wignaraja, G. Can SMEs Participate in Global Production Networks? Evidence from ASEAN Firms? In Global Value Chains in a Changing World; Elms, D.K., Low, P., Eds.; World Trade Organization: Geneva, Switzerland, 2013.

45. Lifset, R.; Anex, R. The Indirect Effects of Industrial Ecology. J. Ind. Ecol. 2009, 13, 347-349. [CrossRef]

46. Ghisellini, P.; Cialani, C.; Ulgiati, S. A Review on Circular Economy: The Expected Transition to a Balanced Interplay of Environmental and Economic Systems. J. Clean. Prod. 2016, 114, 11-32. [CrossRef]

47. Kalmykova, Y.; Sadagopan, M.; Rosado, L. Circular economy-From review of theories and practices to development of implementation tools. Resour. Conserv. Recycl. 2018, 135, 190-201. [CrossRef]

48. Nassos, G.; Avlonas, N. The Need and Growth of a Circular Economy. In Practical Sustainability Strategies: How to Gain a Competitive Advantage; Avlonas, N., Nassos, G., Eds.; John Wiley \& Sons: New York, NY, USA, 2020; pp. 127-136. [CrossRef]

49. Circular Economy and Benefits for Society. Available online: http://www.clubofrome.org.ua/wp-content/ uploads/2017/08/The-Circular-Economy-CoR_UA-2.pdf (accessed on 11 October 2019).

50. Law of Ukraine “On Waste” No. 87/98-BP. Available online: https://zakon.rada.gov.ua/laws/show/187/98$\%$ D0\%B2\%D1\%80 (accessed on 10 October 2019).

51. Ordinance of the Cabinet of Ministers of Ukraine No. 820-p “On Approval of the National Waste Management Strategy in Ukraine until 2030". Available online: https://zakon.rada.gov.ua/laws/show/820-2017-p (accessed on 21 October 2019).

52. State Statistics Service of Ukraine. Available online: http://www.ukrstat.gov.ua (accessed on 21 October 2019).

53. Puchko, R. Circular Economy in Ukraine. Available online: https://www.agroberichtenbuitenland.nl/ documenten/publicaties/2018/06/17/ua-circular-economy-english?fbclid=IwAR0zCYRXRHu2Yjc2jJcv_ suUQmfmslyHcYRgUPGUASF0c93aj_qGCFmhcKI (accessed on 20 December 2018). 
54. Tukker, A. Product services for a resource-efficient and circular economy-A review. J. Clean. Prod. 2015, 97, 76-91. [CrossRef]

55. Achieving 'Growth Within' a €320-Billion Circular Economy Investment Opportunity Available to Europe up to 2025. Available online: https://www.ellenmacarthurfoundation.org/assets/downloads/publications/ Achieving-Growth-Within-20-01-17.pdf (accessed on 20 May 2020).

56. Avraamidou, S.; Baratsas, S.G.; Tian, Y.; Pistikopoulos, E.N. Circular economy-A challenge and an opportunity for process systems engineering. Comput. Chem. Eng. 2020, 133, 106629. [CrossRef]

57. Allwood, J.M. Squaring the Circular Economy. In Handbook of Recycling; Elsevier: Amsterdam, The Netherlands, 2014; pp. 445-477. [CrossRef]

58. EU Best Practices: Circular Economy Action Plan. Available online: https://www.switchtogreen.eu/ /wordpress/wp-content/uploads/wp-post-to-pdf-enhanced-cache/1/circular-economy-strategy.pdf (accessed on 10 May 2020).

59. Cristoni, N.; Tonelli, M. Perceptions of Firms Participating in a Circular Economy. Eur. J. Sustain. Dev. 2018, 7, 105-118. [CrossRef]

60. Michelini, G.; Moraes, R.N.; Cunha, R.N.; Costa, J.M.H.; Ometto, A.R. From Linear to Circular Economy: PSS Conducting the Transition. Procedia CIRP 2017, 64, 2-6. [CrossRef]

61. Europe Goes Circular: Outlining the Implementation of a Circular Economy in the European Area. Available online: https://www.rli.nl/sites/default/files/rli_eu_goes_circular_-_eeac_working_group_on_ circular_economy_def_1.pdf (accessed on 10 December 2019).

62. Razminiene, K. Circular economy in clusters' performance evaluation. Equilib. Q. J. Econ. Econ. Policy 2019, 14, 537-559. [CrossRef]

63. Ślusarczyk, B.; Kot, S. Solution for sustainable development: Provisions limiting the consumption of disposable plastic carrier bags in Poland. J. Secur. Sustain. Issues 2018, 7, 449-458. [CrossRef]

64. Ślusarczyk, B.; Baryń, M.; Kot, S. Tire industry products as an alternative fuel. Pol. J. Environ. Stud. 2016, 25, 1263-1270. [CrossRef]

65. Lieder, M.; Rashi, A. Towards circular economy implementation: A comprehensive review in context of manufacturing industry. J. Clean. Prod. 2016, 115, 36-51. [CrossRef]

66. Kirchherr, J.; Reike, D.; Hekkert, M. Conceptualizing the circular economy: An analysis of 114 definitions. Resour. Conserv. Recycl. 2017, 127, 221-232. [CrossRef]

67. Sanchez-Ortiz, J.; Rodríguez-Cornejo, V.; Del Río-Sánchez, R.; García-Valderrama, T. Indicators to Measure Efficiency in Circular Economies. Sustainability 2020, 12, 4483. [CrossRef]

68. Geng, Y.; Fu, J.; Sarkis, J.; Xue, B. Towards a national circular economy indicator system in China: An evaluation and critical analysis. J. Clean. Prod. 2012, 23, 216-224. [CrossRef]

69. Geng, Y.; Zhang, P.; Côté, R.P.; Fujita, T. Assessment of the national eco-industrial park standard for promoting industrial symbiosis in China. J. Ind. Ecol. 2009, 13, 15-26. [CrossRef]

70. Smol, M.; Marcinek, P.; Duda, J.; Szołdrowska, D. Importance of Sustainable Mineral Resource Management in Implementing the Circular Economy (CE) Model and the European Green Deal Strategy. Resources 2020, 9, 55. [CrossRef]

(C) 2020 by the authors. Licensee MDPI, Basel, Switzerland. This article is an open access article distributed under the terms and conditions of the Creative Commons Attribution (CC BY) license (http://creativecommons.org/licenses/by/4.0/). 